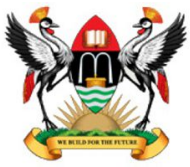

East African School of Higher Education Studies \& Development
Makerere Journal of Higher Education

ISSN: 1816-6822; 10 (2) (2019) $119-131$

DOI: http://dx.doi.org/10.4314/majohe.v10i2.9

(C) The Author(s) 2019

Reprints \& permission: EASHESD

http://ajol.info/majohe

\title{
Budget Implementation Strategies and Organisational Effectiveness in Colleges of Education in Nigeria
}

\author{
Omosidi A. S. ${ }^{1, *}$, Oguntunde D. A. ${ }^{2}$, Oluwalola F. K. ${ }^{1}$, Ajao R. L. ${ }^{3}$ \\ ${ }^{1}$ University of Ilorin [*Corresponding author: omosidi.as@unilorin.edu.ng]; ${ }^{2}$ Ministry of \\ Tertiary Education, Science and Technology, Kwara State; ${ }^{3}$ Ministry of Education and Human \\ Capital Development, Kwara State
}

\begin{abstract}
This study examined the relationship between budget implementation strategies and organisational effectiveness in colleges of education in Nigeria. Simple random sampling was used to select 24 colleges of education while stratified random sampling was used to select 432 staff as participants in the study. A questionnaire tagged "Budget Implementation Strategies Questionnaire" (BISQ) and one pro-forma titled "Student Academic Achievement Schedules" (SAAS) were used to collect data. The instruments were validated by experts. The reliability coefficient for BISQ was 0.76. Pearson's Product Moment Correlation (PPMC) was used to test the hypotheses while stepwise multiple regression was used to determine the level of contribution of each independent variable to the dependent variable. The findings were that there was a significant relationship between budget implementation strategies and organisational effectiveness in the colleges. It was concluded that it is necessary to provide technical assistance to units and departments concerned with preparing workable fiscal budgets.
\end{abstract}

Keywords: Planning; Budgeting; Reform.

\section{$1 \quad$ Introduction}

A common characteristic of planning in African countries is the dominant role of the public sector. This is particularly so in educational planning where the growth of government schools is a prominent feature of educational development (Forojalla, 1993). Details of public sector programmes are normally included in government budgets at both the national and lower levels of government. Hence, as additional objectives for action, the budget plays a role in planning, programming and controlling educational cost during the plan period. Omosidi and Abdulkareem (2012) stated that budget is one of the principal instruments 
with which the authorities of an educational system express their priorities for a period of time. In fact, budgeting offers the management the opportunity to examine detail of financial plans for both general situation of the economy and the economic inter-relationship among all the educational systems of various activities.

Budget prepares the organisation so as to ensure that the required resources are available at the right time and in the right amount in order to facilitate the completion of proposed actions and accomplish planned objectives. Consequently, there is usually more detailed costing in the budget than in the plan. Nevertheless, both the plan and the budget provide a comprehensive picture of what is intended and expected and the means by which the objectives are achieved. This makes the budget a powerful tool in the planning process. Budget thus controls the implementation of the plans through the programming of its cost and ensuring the annual appropriation of funds needed.

However, the implementation of budget is as important as the budget plan itself. This is because if budget is not effectively implemented there is the tendency of misappropriation and/or mismanagement of funds allocated to institutions. Brennan (1999) reported that even though budget implementation strategies are conditions by the nature of the educational institutions and authority in higher education system, they are capable of raising the profile of teaching and learning in higher institutions. Omosidi and Oguntunde (2016) noted that budget implementation controls the financial behaviour of administrators in a school system because it prevents waste or reckless spending of funds provided for various educational services. Studies have also established that some educational administrators have been found for misappropriation of funds which were meant for education purposes. For example, Okorie (2015) elucidated that school managers in Nigeria tend to be transferred or even lose their jobs due to fiscal mismanagement.

It is against this background that the study was set to examine the relationship between budget implementation strategies and organisational effectiveness using students' academic achievement in Nigeria colleges of education. It is assumed that the implication of this to educational planning is that the quality of input injected into the educational system would probably determine the output of the system. In other words, if budget is effectively implemented by the heads of colleges of education there is the tendency for the institutions to be effective by achieving target goals which are often expressed through students' academic achievement, if all other factors remain constant.

\subsection{Purpose of the Study}

The main purpose of the study was to examine the relationship that existed between budget implementation strategies and organisational effectiveness in Nigeria colleges of education. Specifically, the objectives of this study were: 
1. to find out the relationship between the use of budget committee and organisational effectiveness in Nigeria colleges of education;

2. to examine the relationship between the use of call circular and organisational effectiveness in public Nigeria colleges of education; and

3. to determine the relationship between the use of budgetary control mechanism and organisational effectiveness in Nigeria colleges of education.

\subsection{Research Hypotheses}

The general hypothesis is that there is no significant relationship between budget implementation strategies and organisational effectiveness in Nigeria colleges of education. The following operational hypotheses guided the study:

$\mathbf{H O}_{1}$ : There is no significant relationship between the use of budget committee and organisational effectiveness in Nigeria colleges of education.

$\mathbf{H O}_{2}$ : There is no significant relationship between the use of call circular and organisational effectiveness in Nigeria colleges of education.

$\mathbf{H O}_{3}$ : There is no significant relationship between the use of budgetary control mechanism and organisational effectiveness in Nigeria colleges of education.

\subsection{Significance of the Study}

This study is concerned about ensuring prudent utilization of funds meant for institutional development by the college administrators. The study would also show the details of plans and programmes of educational institution which would give coherence and direction to the actions and decisions taken by managers on how to implement their budget plans in the institutions. The study would constitute a helpful resource to agencies such as Federal and State Ministries of Education during the annual budget implementation in the appointment and requirement of academic staff and administrators of public Nigeria colleges of education.

\subsection{Scope and Limitation of the Study}

This study covered all the 67 public colleges of education in Nigeria as at the time of the study. However, the colleges used were limited to 24 federal and state-owned ones. The study covered three academic session (2012/13-2014/ 15) in all the sampled institutions.

There were many indicators of budget implementation strategies including the appointment of budget committee, use of call circular, use of budgetary controls, goals/needs prioritisation, use of fund raising, tapping resources, use of communication strategy, and use of timelines. But this study was limited to the use of budget committee, use of call circular and use of budgetary controls only. 
The indicators of organisational effectiveness include students' career development, faculty professional development, general employment satisfaction, students' academic and personal development, system openness, teaching effectiveness, students' achievement, research publications and community services. However, this study was limited to students' academic success in moderated final examination for a three-year period (2012-2014).

\section{$2 \quad$ Related Literature}

The relationship between budget implementation strategies and organisational effectiveness cannot be overemphasised. Budget implementation strategies are the linking-pins to organisational effectiveness. Some researchers have established that effective budget implementation strategies, to a great extent, are crucial to quality goal achievement in all organisations. For example, Brendis (1999) enumerated the impact of budget implementation strategies on goal achievement of educational institutions as thus:

1. It promotes broad based participation during budget planning process and strong organisational support during implementation;

2. It serves as opportunity to focus energies and co-ordinate resources across department, engaged efforts of teachers, students and parent to improve on learning outcome;

3. It enables the budget committee to provide a channel for gathering and distributing information and research findings, recommend budget initiatives for administrative approval and implementation and co-ordinate institutional activities;

4. It improves the organisation through the definition of clear policy for implementing the budget;

5. It Provides professional development and careful planning to overcome inter-departmental conflict and barrier that may impede equitable integrations of resources necessary to achieve school organisation goals; and

6. It provides bench-marking (i.e. best practices) that lead to superior performance in the education industry.

Brennan (1999) reported that even though budget implementation strategies are conditioned by the nature of the individual institutions and authority in higher education system, they are capable of raising the profile of teaching and learning in the institutions. Brennan (1999) added that the overall impact increased when the mechanism gained legitimacy at the faculty and departmental level, and that increased centralisation and managerialism were the characteristics at the level of the institution. Watts (1992) studied major OECD countries looking at budget 
implementation strategies and academic goal achievement of the eight commonalities. Watts found that input measures like the number of students' enrolled with goal or result-oriented estimates of outcomes, such as quality and employability of graduate increased. Johnstone (1998) confirmed that colleges and universities that adopted budget implementation strategies were able to increase their legitimacy and chances of survival.

Furthermore, a study by the National Association of State Budget Office (NASBO, 1996) which reviewed measures adopted by 38 states to ensure steady supply of students in higher educational institutions, found that budget implementation strategies enhance judicious expenditure of funds allocated for the purpose. As a result, students who graduated in high school in three consecutive academic years maintained a GPA of at least 3.0 out of 4.0. Albright (2000) also reported that in the year 1998, when $100 \%$ of state higher education funds were allocated on the basis of institutional performance on 37 specific indicators which included the use of budget implementation strategies such as financial guideline, staff training and development, the Total Quality Assessment (TQA) which included student entry profiles, expenditure per student, the progression and completion rate increased. Albright further stressed that indicators relating to research publication, grants, number of assistants and students employed and research environment increased in manifold.

Relevant empirical studies were also carried out to determine the relationship between budget implementation strategies and academic goal achievement. For example, Munn (2004) carried out a study on budget implementation strategies and administrative goal achievement in Korea higher education institutions. The budget implementation strategies investigated consisted of: (1) selection of special task force to implement the budget procedure; (2) development of budget time table; (3) preparation of budget manual; and (4) development of follow-up training indicating stages of the budget cycle. The study used 25-item questionnaire statements to collect information from 250 administrative officers. Spearman ranking order was employed to analyse the data collected. The study found that selection of special task force to establish budget implementation procedure ranked highest among the strategies that achieved the goals and objective of Korean higher institutions of learning. In another study conducted by Oguntunde (2007) on the relationship between communication of budget information and goal achievement, it was discovered that communication of information on budget preparation and administration enhanced the motivation of budget officers to achieve their organisational goals. Furthermore, Abdullahi (2015) investigated the relationship between setting budget priorities and achievement of the goals of North-central states in Nigeria. The study used both the descriptive and inferential statistics to analyse the data collected from 100 respondents. The study found that there was a positive significant relationship 
between setting budget priorities and achievement of quality teaching and learning in North-Central states higher educational institutions in Nigeria.

Stiefel (2001) investigated the relationship between use of budgetary control mechanism and students' academic achievement. The sub-variables of budgetary control used include pre-spending auditing, concurrent spending auditing and post-spending auditing. Also, students' academic achievement was measured using student enrolment rate, student mobility rate and student academic achievement in standardized final examination. In the study, 44 schools were sampled in 13 school districts in US, Canada and Australia. The study was a descriptive survey of the correlational type. The simple random sampling technique was used to select the 44 schools' decision makers who were accountable for students' academic achievement. The study used two questionnaires tagged: "Budgetary Control Mechanism Rating Scale" (BCMRS) and "Student's Academic Achievement Rating Scale" (SAARS). Data collected were analysed using the descriptive and the t-test statistics. Consequently, Stiefel's (2001) findings revealed that: (1) pre-spending auditing was significantly related to students' enrolment rate at (1.45); (2) concurrent spending auditing was related to students' mobility rate at $(0.12)$; (3) while post- spending auditing was significantly related to student achievement in fourth and fifth grade during the study period at $(0.31)$.

Stiefel's (2001) study and the present study are quite similar. This study examined the relationship between budget implementation strategies and organisational effectiveness. Budgetary control mechanism was among the indicators of implementation strategies considered. Students' academic achievement in final NCE examination was also used. Just like Stiefel's study, the research design of the present study is a descriptive survey of the correlational type. Simple random sampling technique was used to select 24 out of the 67 Colleges and 432 administrators and educators out of the 680 in the colleges involved in the study. To collect data on the relationship between implementation strategies and organisational effectiveness, "Budget Implementations Strategies Questionnaire" (BISQ) was used.

Instead of the t-test statistics that was used by Stiefel's study, the present study adopted the Pearson's Product Moment Correlation and Stepwise multiple Regression analysis to test the significant relationship between the two variables and examined the level of contributions of each independent of sub-variables on organisational effectiveness at .05 level of significance.

\section{$3 \quad$ Methodology}

The population of the study consists of 75 colleges of education in Nigeria as at the time of the study. These were 20 Federal, 38 State, 16 Private and one Army 
colleges of education (NCCE, 2016). Out of these, only 24 colleges were selected using the simple random sampling technique. Furthermore, the stratified random sampling technique was used to select 432 out of the 680 academic and nonacademic staff as participants for the study.

A researcher-designed questionnaire tagged, "Budget Implementation Strategies Questionnaire" (BISQ) and "Students" Academic Achievement Scheduled" (SAAS) were used to collect relevant data for the study. BISQ comprised of 30 items which were on a 3 point Likert Scale (Always so, Sometimes so and Never so). "Always so" attracted 3 points, "Sometimes so" attracted 2 points, while "Never so" attracted 1 point. Respondents indicated with a tick of the frequency with which their departments adopted any of the criteria of budget implementation strategies as applicable to their colleges. The "Students' Academic Achievement Format Schedule" (SAAS) is a format used to collect final year NCE students' examination results for a period of 3 years (2012-2014).

The instruments were given to experts in the dependents of Educational Management and Social Sciences Education for validation which led to the development of the final instruments used for the study. The reliability of BISQ was determined using the split-half method. The reliability of the test yielded a value of 0.76 .

The copies of the questionnaire were administered on 432 participants. The inferential statistics, which comprises the Pearson's Product Moment Correlation and stepwise multiple regression analysis, were used to test the formulated hypotheses to determine the level of contribution of each independent variable on the dependent variable at 0.05 level of significance.

\section{$4 \quad$ Findings and Discussion}

In the subsections that follow, the findings of the study are presented according to the hypotheses stated.

\subsection{Main Hypothesis}

The main hypothesis stated that "there is no significant relationship between budget implementation strategies and organisational effectiveness in Nigeria colleges of education". The findings on the hypothesis are summarized in Table 1. 
Table 1: Budget implementation strategies and organisational effectiveness

\begin{tabular}{|c|c|c|c|c|c|c|}
\hline Variables & $\mathrm{N}$ & Mean & SD & Cal. r-value & Crit. r-value & Decision \\
\hline $\begin{array}{l}\text { Budget } \\
\text { Implementation } \\
\text { Strategies }\end{array}$ & 432 & 45.61 & 11.26 & 0.7430 & 0.195 & $\begin{array}{l}\mathrm{HO} \\
\text { Rejected }\end{array}$ \\
\hline $\begin{array}{l}\text { Organisational } \\
\text { Effectiveness }\end{array}$ & 432 & 55.82 & 24.01 & & & \\
\hline
\end{tabular}

Table 1 reveals that the calculated r-value of the Pearson's Product Moment Correlation is 0.74 which is greater than the critical r-value of 0.195 at 0.05 level of significance with 430 degree of freedom. Hence, the null hypothesis was rejected. Therefore, there is significant relationship between budget implementation strategies and organisational effectiveness in Nigeria colleges of education.

The findings of this study was in consonance with the outcome of Oguntunde's (2007) study which identified a significant relationship between budget implementation strategies and students' academic achievement. Conversely, the outcome of the study was in disagreement with Ifedi (1999) who believes that the use of budget implementation strategies have also become imperative as heaps of allegations were levied against government administrators of organisations where budgeting has only been an annual ritual but its implementation was zero. However, the findings is an evidence that budget is a reflection of the degree to which the authorities attach importance to the funding of the colleges.

\subsection{Operational Hypotheses}

HO$_{1}$ : There is no significant relationship between the use of budget committee and organisational effectiveness in Nigeria colleges of education.

Table 2: Use of budget committee and organisational effectiveness

\begin{tabular}{|c|c|c|c|c|c|c|}
\hline Variables & $\mathrm{N}$ & Mean & SD & Cal. r-value & Crit. r-value & Decision \\
\hline Use of Budget & 432 & 32.15 & 16.07 & 0.2958 & 0.195 & HO1 \\
\hline Committee & & & & & & Rejected \\
\hline $\begin{array}{l}\text { Organisational } \\
\text { Effectiveness }\end{array}$ & 432 & 55.82 & 24.01 & & & \\
\hline
\end{tabular}

Table 2 reveals the result of correlational analysis testing the relationship between the use of budget committee as budget implementation strategy and organisational effectiveness in Nigeria colleges of education. The calculated $r$ value is greater than the critical r-value $(0.2958>0.195)$ at 0.05 level of significance for 430 degrees of freedom. Therefore, the hypothesis which states 
that there is no significant relationship between the use of budget committee and organisational effectiveness was rejected. The implication of the result is that the use of budget committee as a budget implementation strategy had a positive significant relationship with organisational effectiveness in Nigeria colleges of education.

Budget committee is a formalised structure that prepares and monitors budget plans of any organisation. It is usually headed by an accountant because of his professional skill to provide assistance in the process of budgeting. Furthermore, a budget committee must have a budget centre where the budget plan of all departments will be collated before producing the final master budget.

The result of this study might be as a result of the administrators of colleges of education allowing the use of budget committee, as their implementation strategy, to perform their duties without any interference. This assertion is in line with Brendis's (1999) that budget committee will focus their energies and coordinate the available resources most effectively to achieve organisational goals, if there were no distractions.

$\mathbf{H O}_{2}$ : There is no significant relationship between the use of call circular and organisational effectiveness in Nigeria colleges of education.

Table 3: Use of call circular and organisational effectiveness

\begin{tabular}{lllllll}
\hline Variables & $\mathrm{N}$ & Mean & SD & Cal. r-value & Crit. r-value & Decision \\
\hline Use of Call Circular & 432 & 72.79 & 36.39 & 0.4405 & 0.195 & $\begin{array}{l}\text { HO2 } \\
\text { Rejected }\end{array}$ \\
$\begin{array}{l}\text { Organisational } \\
\text { Effectiveness }\end{array}$ & 432 & 55.82 & 24.01 & & & \\
\hline
\end{tabular}

Table 3 indicates the result of correlational analysis testing the relationship between the use of call circular and organisational effectiveness in Nigeria colleges of education. The calculated $r$-value is greater than the critical $r$-value $(0.44>0.195)$ at 0.05 level of significance with 430 degree of freedom. Consequently, the hypothesis which states that there is no significant relationship between the use of call circular and organisational effectiveness was rejected.

The importance of call circular as a budget implementation strategy in any organisation has been established. For instance, Balogun (2003) stated that call circular from spending agencies on how to take full cognisance of the price of the country so that their proposed revenue and expenditure will be as much as possible achieve their individual organisation's objectives. That is, call circular guide the administrators on how to carry out an effective budgeting. As a guide, it focuses on how to generate revenue and how the revenue generated can be allocated to all heads in the organisation, using formulas and ratios. 
$\mathbf{H O}_{3}$ : There is no significant relationship between budgetary control mechanism and organisational effectiveness in Nigeria colleges of education.

Table 4: Budgetary control mechanism and organisational effectiveness

\begin{tabular}{|c|c|c|c|c|c|c|}
\hline Variables & $\mathrm{N}$ & Mean & SD & Cal. r-value & Crit. r-value & Decision \\
\hline $\begin{array}{l}\text { Budgetary Control } \\
\text { Mechanism }\end{array}$ & 432 & 38.27 & 19.13 & 0.3926 & 0.195 & $\begin{array}{l}\mathrm{HO}_{3} \\
\text { Rejected }\end{array}$ \\
\hline $\begin{array}{l}\text { Organisational } \\
\text { Effectiveness }\end{array}$ & 432 & 55.82 & 24.01 & & & \\
\hline
\end{tabular}

Table 4 reveals the result of correlation analysis testing the relationship between budgetary control mechanism committee and organisational effectiveness in Nigeria colleges of education.

The calculated r-value is greater than the critical r-value $(0.39>0.195)$ at 0.05 level of significance with 430 degree of freedom. Thus, the hypothesis which state that there is no significant relationship between the use of budgetary control mechanism and organisational effectiveness in Nigeria colleges of education was rejected. The result of the study agreed with Stiefel's (2001) that budgetary controls had significant association with students' academic achievement in educational institutions in the United States of America. The result also agreed with Kirks' (2003) that budget controls ensure that scarce resources are used appropriately to achieve the goals of any organisation.

Budget controls as implementation strategy include: consistent monitoring of procedures, records and reports of fiscal budget of any organisation. It is a systematic examination and evaluation of accounts of an organisation in order to offer advice to the administrators on the fitness and reliability of their budget plan. In addition, budget controls ensure that budget procedures of any organisation comply with the standard, law and goal of accounting system. Again, budget controls ensure that an organisation's allocation to personnel, property, space development and provision of social services are disturbed as efficiently as possible. It ensures that the organisational goals are the only determinants of budgeting exercise.

Table 5: Relative contribution of elements of budget implementation to organisational effectiveness

\begin{tabular}{llllll}
\hline Variable & Beta & Standard error & $\mathrm{F}$ & Sign. $\mathrm{f}$ & Remark \\
\hline $\mathrm{X}_{1}$ & 0.5059 & 0.35091 & 0.2958 & 0.05386 & Significant \\
$\mathrm{X}_{2}$ & 0.3779 & 0.13312 & 0.4405 & 0.8259 & Significant \\
$\mathrm{X}_{3}$ & 0.4874 & 0.11582 & 0.3926 & 0.3402 & Significant \\
Constant & 7.1337 & 5.35524 & & & \\
\hline
\end{tabular}


Substituting the parameters given in Table 5 in the fundamental regression equation gives: $\mathrm{Y}^{1}=7.1337+0.05059 \mathbf{X}_{\mathbf{1}}+0.3779 \mathbf{X}_{\mathbf{2}}+0.4874 \mathbf{X}_{\mathbf{3}}+5.35524$, where $\mathrm{Y}^{1}$ is organisational effectiveness; $\mathrm{X}_{1}, \mathrm{X}_{2}$ and $\mathrm{X}_{3}$ are use of budget committee, use of call circular and use of budgetary control mechanism, respectively.

This shows that for every point increase in the prediction variables of $\mathbf{X}_{\mathbf{1}}, \mathbf{X}_{\mathbf{2}}$ and $\mathbf{X}_{3}$ there will be an increase of 0.5059 (51\%), 0.3779 (38\%) and $0.4874(49 \%)$ in the predicted criterion $\mathrm{Y}^{1}$, respectively. This means a unit change in use of budget committee $\left(\mathrm{x}_{1}\right)$ will have $51 \%$ change in organisational effectiveness $\left(\mathrm{Y}^{1}\right)$, while a unit change in use of call circular $\left(\mathbf{X}_{2}\right)$ will mean $38 \%$ change in organisational effectiveness $\left(\mathrm{Y}^{1}\right)$. Furthermore, a unit change in use of budgetary control mechanism $\left(\mathbf{X}_{3}\right)$ will have $49 \%$ change in organisational effectiveness $\left(\mathrm{Y}^{1}\right)$. The low contribution of use of call circular as budget implementation strategy $(38 \%)$ on organisational effectiveness among other strategies may be associated with the inabilities of most of the heads of Nigeria colleges of education to the use of the financial resource available for the purpose for which the resource was proposed for in the colleges between 2012 and 2014.

From the similarities, the three independent variables contributed differentially to organisational effectiveness as shown by the observed standard regression weight beta $(\mathrm{B})$ values for each variable.

\section{Conclusion and Recommendations}

It is concluded that budget implementation strategies were indispensable to organisational effectiveness. The conclusion drawn from the findings of this study are that: the use of budget committee had a significant relationship with organisational effectiveness; the use of call circular was also found to significantly determine organisational effectiveness; and the use of budgetary control mechanism was identified as a significant variable that determine organisational effectiveness in Nigeria colleges of education. Based on the findings of this study, the following recommendations were made:

1. To have sound budgeting implementation in the colleges under review, it is necessary to provide technical assistants to units and departments concerned on how to prepare a workable fiscal budget for effective and efficient implementation. This can be achieved by adapting the budget manual of the federal/state government on how to implement her plan on education for each year.

2. There is the need to formalise the structure of the budget committee as implementation strategy in each college in order to improve in the 
preparation of budget planning of the colleges; there is the need to have a manager who will put the budget together and monitor its implementation.

3. The use of call circular as implementation strategy may be used to instruct in these colleges to take full cognisance of the price structure in the country so that their proposed revenue and expenditure will reflect as much as possible the existing economic reality and the future of the country.

4. In order to make the use of budgetary control mechanism as implementation strategy effective, there must be a co-operation among all those concerned with the preparation of the budget. Similarly, detail operations of the colleges should be explained to those involved.

\section{References}

Abdullahi, A.O. (2015). Relationship between setting budget priority and achievement in North West Colleges of Education in Nigeria. An unpublished Ph.D. Thesis, Department of Educational Planning and Administration, ABU, Zaria, Nigeria.

Albright, B. N. C. (2000). Performance based funding Network news, 17 (1)

Balogun, A. N. (2003). Budgeting preparation; analysis and appraisal. Being a seminar organized by the National Assembly at the Kanji Lake National Park, New- Bussa, Nigeria.

Brendis, A. S. (2004). Responsibility centre management: pilot interim procedures manual. Retrieved from http://www.responsibility management.htm on 28/1/2013.

Brennan, J. (1999). Evaluation of lighter re-education in Europe. In M. Henkel and $\mathrm{B}$. little (Eds.). Changing relationship between higher education and the state. London: Jessia Kingsley publisher

Forojalla, S .B. (1993). Educational planning for development. London: The Macmillan press Ltd

Ifedi, A. B. (1999). Budgeting and budget system. Ibadan: Spectrum Publisher Ltd.

Johnstone, D. B. (1998): The financing and management of higher education: $A$ Status report on worldwide reform preparation supported by the World Bank. Retrieved from http://www.worldwidebank.org/htm/extdr/edu/postbasc $/ \mathrm{htm}$.

Munn, P. (2004). Developed management of school in practice. The Scottish council for research in education. Retrieved from http://www.screac.uk/htm on $22 / 09 / 2014$.

Oguntunde, D. A (2007): Relationship among budgeting system, implementation strategies and students' academic achievement in colleges of education, 
Nigeria. An unpublished Ph.D. Thesis, Department of Educational Management, University of Ilorin, Nigeria.

Okorie, A. N. (2015). Towards effective fiscal resources management system in the Nigerian secondary schools: some guideline. Journal of Education in Developing Areas (JEPAS), 23(2), 440-458.

Omosidi, A. S. \& Abdulkareem, A. Y (2012). Financial control system and organisational effectiveness of colleges of legal and Islamic studies in Nigeria. International Journal of Educational Management, 10(1), 9-19.

Omosidi, A. S. \& Oguntunde, D. A. (2016). Relationship between budgeting system, and students' academic achievement in Colleges of Education, Nigeria. Ilorin Journal of Education, 35, 183-195.

Stiefel, L. A. E. (2001). School budgeting and school performance. Working paper, New York: New York University Press.

Watts, R. (1992). University and public policy. In J. Cutt, 5 \& R. Dobello (Eds.). Public purse, public purpose: Autonomy and accountability in the givers of academic. Canada: Institute for research on public policy and Canadian comprehensive auditing foundation. 